\title{
THE ASSESSMENT OF THE POSSIBILITIES FOR THE LITHUANIAN FLEET TO COMPLY WITH NEW ENVIRONMENTAL REQUIREMENTS
}

\author{
Irina Panasiuk ${ }^{1}$, Sergejus Lebedevas ${ }^{2}$ \\ ${ }^{1}$ Dept of Ship Engineering, Klaipeda University, Lithuania \\ ${ }^{2}$ Maritime Institute, Klaipeda University, Lithuania
}

Submitted 1 July 2013; accepted 16 October 2013

\begin{abstract}
The article analyses the economic impact of compliance of the Lithuanian fleet with the new requirements of the MARPOL 73/78 Annex VI, which sets a limit for sulphur content in marine fuel to $0.1 \%$ in 2015 in Emission Control Area (ECA) and to $0.5 \%$ in 2020 globally. The assessment of several most realistic options of complying with the new requirements is presented in the article. Each of these methods is assessed by means of uncovering the economic and practical issues associated with applying their implementation to the Lithuanian fleet. An overview of Lithuanian fleet was carried out to choose the particular vessels for analysis. A group of 10 vessels was selected to compare the benefits and limitations of using low sulphur fuel and scrubbers. The economic impact of using low sulphur fuel or installing the scrubber for each vessel is also assessed in the article.
\end{abstract}

Keywords: Lithuanian fleet, low sulphur fuel, fuel price spread, fuel consumption, liquefied natural gas, scrubbers, benefits, limitations.

Reference to this paper should be made as follows: Panasiuk, I.; Lebedevas, S. 2014. The assessment of the possibilities for the Lithuanian fleet to comply with new environmental requirements, Transport 29(1): 50-58.

http://dx.doi.org/10.3846/16484142.2014.896828

\section{Introduction}

The International Maritime Organization (IMO) through the MARPOL 73/78 Annex VI sets certain limits on sulphur oxides $\left(\mathrm{SO}_{\mathrm{x}}\right)$ and nitric oxides $\left(\mathrm{NO}_{\mathrm{x}}\right)$ emissions from ship exhausts: the content of $\mathrm{SO}_{\mathrm{x}}$ in marine fuel should be reduced to $0.1 \%$ by 2015 in Emission Control Area (ECA) and globally to $0.5 \%$ in 2020 ; in case of $\mathrm{NO}_{\mathrm{x}}$, between Tier I in 2000 and Tier II in 2011 the emission was limited by $20 \%$, while with the following Tier III it will be limited by $80 \%$ in 2016 (MEPC 2008; Schembari et al. 2012; Fridell et al. 2008).

Choosing the best way to comply with the new requirements is vital for maritime industry. Regulations for ECAs are now enforced across many countries and there are further designated zones under discussion (Fig. 1).

New requirements could have a strong economic impact considering that approximately $80 \div 90 \%$ of merchant vessels enter an ECA in their lifetime (Boardley 2012).

It is very difficult to compare both $\mathrm{SO}_{\mathrm{x}}$ and $\mathrm{NO}_{\mathrm{x}}$ reduction methods simultaneously. Today only Liquefied Natural Gas (LNG) allows complying with both limita- tions (Lloyd's List 2010a, b). However the use of LNG requires modernization of the existing vessels, which is unsuitable for most of the Lithuanian fleet. LNG is more suitable for new built vessels. Because of a lack of infrastructure, as well as uncertainty over prices, this method remains a concern for the industry, and is not analysed in the article. In turn, the use of low sulphur fuel or installing the scrubbers reduces only $\mathrm{SO}_{\mathrm{x}}$ emissions. It means that additional equipment, like Selective Catalytic Reduction (SCR), would be needed to reduce $\mathrm{NO}_{\mathrm{x}}$ emissions. Unfortunately, it is not easy to combine the scrubbers and SCR. The SCR needs high temperature of $390^{\circ} \mathrm{C}$, which is not possible after wet scrubbing. On the other hand, SCR does not function well with high sulphur content (Kruse 2012).

For the above mentioned reason the following $\mathrm{SO}_{\mathrm{x}}$ reduction methods were selected for analysis in order to simplify the comparison between the most realistic options of reducing the toxicity of ship exhausts:

- low sulphur fuel;

- scrubber.

Both methods have their benefits and limitations, which were compared in regard to the Lithuanian fleet.

Corresponding author: Irina Panasiuk

E-mail: irina.panasiuk@gmail.com 


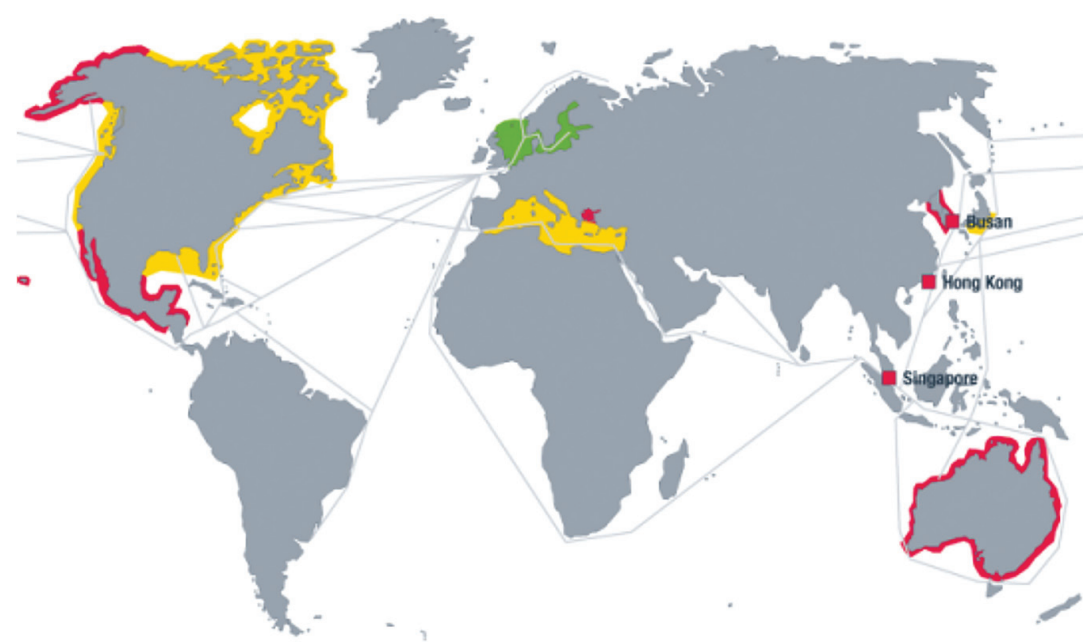

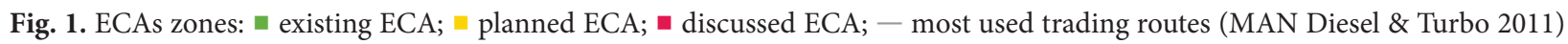

New environmental problems are becoming more and more important. Therefore, an increasing number of scientists devote their studies to this theme. The impact of ship emissions on local air quality and possibilities of ship toxicity reduction are investigated in theirs studies (Poplawski et al. 2011; Lonati et al. 2010; Ytsma et al. 2009; Kohl, Nielsen 1997; Wang, Corbett 2007).

\section{The Overview of the Lithuanian Fleet}

Over the last 20 years the Lithuanian fleet has undergone significant qualitative and quantitative changes. The fleet decreased from 308 vessels in 1994 to 113 in 2013 (Table 1). The gross tonnage has also been reduced from 647000 Gross Register Tonnes (GTR) in 1994 to 402579 GTR in 2013 (LSLA 2013).

In 2005, there were 94 trawlers, 78 trade vessels, 12 tugs and 14 special purpose vessels. Unfortunately, the quantity of vessels of the Lithuanian fleet has changed significantly by 2013 (Table 2 ).

The quantitative reduction of vessels is one of the several troubling problems the Lithuanian fleet has. Along with quantitative changes, the Lithuanian merchant fleet is getting older and today's average vessel age reaches $20 \div 22$ years (Table 3 ).

Operating old vessels become less profitable every year due to their increasing maintenance costs. Furthermore, the Lithuanian fleet is facing new challenges of IMO requirements, which could prove to be a non-surmountable challenge for some vessels. It should be noted that the investment on scrubbers or LNG for ships older than 25 years is unprofitable (Wärtsilä 2012). Another limitation is vessels' deadweight (DNV 2012). It will limit the possibility of eco-refitting of many smallsize vessels in the Lithuanian fleet, such as tugs, special purpose vessels or trawlers.

Table 1. Decrease of the Lithuanian fleet

\begin{tabular}{ccccccc}
\hline \multicolumn{7}{c}{ Number of vessels in each year } \\
\hline 1994 & 2000 & 2005 & 2010 & 2011 & 2012 & 2013 \\
\hline 308 & 279 & 198 & 151 & 141 & 121 & 113 \\
\hline
\end{tabular}

Table 2. Number of vessels registered in the Lithuanian registry in 2013 (LSLA 2013)

\begin{tabular}{|c|c|c|}
\hline Vessels type & Number & GRT \\
\hline \multicolumn{3}{|c|}{ Merchant fleet up to $100 \mathrm{GRT}$} \\
\hline Transport refrigerators & 9 & 28664 \\
\hline Dry cargo ships & 33 & 161317 \\
\hline Passenger ferries & 7 & 164377 \\
\hline \multicolumn{3}{|c|}{ Merchant fleet less than 100 GRT } \\
\hline Dry cargo ships & 1 & 42 \\
\hline \multicolumn{3}{|l|}{ Others } \\
\hline Trawlers & 46 & 42839 \\
\hline Tugs & 12 & 3862 \\
\hline Special purpose vessels & 5 & 1478 \\
\hline
\end{tabular}

Table 3. The average age of the Lithuanian fleet in 2013 (Marine Traffic 2013)

\begin{tabular}{lc}
\hline \multicolumn{1}{c}{ Vessels type } & Average age \\
\hline Trawlers & 30 \\
\hline Special purpose vessels & 28 \\
\hline Transport refrigerators & 22 \\
\hline Tugs & 21 \\
\hline Dry cargo ships & 20 \\
\hline Passenger ferries & 13 \\
\hline
\end{tabular}

\section{The Assessment of the Lithuanian Fleet Feasibility to Comply with $\mathrm{SO}_{\mathrm{x}}$ Requirements}

The assessment of the Lithuanian fleet shows that the mentioned weaknesses and threats complicate the ecorefitting of the fleet. It is now clear that only a group of vessels, which are not older than 25 years, can be chosen for eco-refitting. Relying on this the group of vessels was selected for further analysis of feasibility of Lithuanian fleet to comply with IMO requirements. The analysis results are shown in Table 4 (DFDS Seaways 2013; LSCo 2013; Marine traffic 2013; Wärtsilä 2007; Motor Ship 2005). 
Table 4. The parameters of the selected vessels

\begin{tabular}{|c|c|c|c|c|c|}
\hline Vessels type & 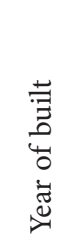 & 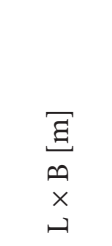 & $\frac{5}{3}$ & 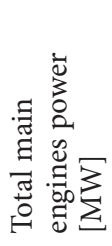 & 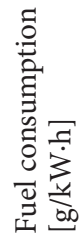 \\
\hline Ferry & 2010 & $199 \times 27$ & 8400 & 25.20 & 172 \\
\hline Ferry & 2009 & $199 \times 27$ & 8400 & 24.00 & 172 \\
\hline Ferry & 1999 & $186 \times 26$ & 7500 & 18.90 & 178 \\
\hline Ferry & 1997 & $186 \times 26$ & 7115 & 15.60 & 172 \\
\hline Ferry & 1994 & $191 \times 26$ & 7665 & 10.60 & 174 \\
\hline Reefer & 1993 & $134 \times 21$ & 8045 & 7.06 & 174 \\
\hline Reefer & 1991 & $121 \times 17$ & 5065 & 5.30 & 174 \\
\hline Reefer & 1989 & $136 \times 18$ & 6565 & 4.60 & 184 \\
\hline Containership & 1997 & $122 \times 19$ & 7300 & 5.85 & 178 \\
\hline Containership & 1999 & $100 \times 16$ & 3739 & 3.25 & 172 \\
\hline
\end{tabular}

The selection of the particular group of vessels is based on the average age and operating area of the vessel. In this way 10 vessels, among them 5 passenger ferries, 3 refrigerators and 2 containerships were selected and their quality of using alternatives of reduction of the toxicity of ship exhausts is evaluated in the article. The following parameters of vessels were taken into account: vessel age, size and deadweight, engine type and power, fuel type and its consumption. The use of low sulphur fuel and scrubbers were compared with each other.

Low sulphur fuel. $\mathrm{SO}_{\mathrm{x}}$ can be reduced directly by lowering the content of sulphur in fuel. Fuel cost is a major part of vessel's operating costs. That is why analysed refrigerators and containerships engines have been designed to operate primarily using lower cost Intermediate Fuel Oil (IFO) and while Marine Diesel Oil (MDO) is the primary fuel for passenger ferries alone. The specifications of the most common marine fuels are given in Table 5 (UK Chamber of Shipping 2013).

This illustrates that, currently, the only fuel that meets the $0.1 \% \mathrm{SO}_{\mathrm{x}}$ requirements is Low Sulphur Marine Gas Oil (LSMGO) - 100\% distillate which has not yet been certified by ISO standards. Fuel switching can cause various engine fuel system operational problems, such as purifier or filter clogging, fuel pump scoring or failure, severe cylinder liner wear, fuel injector seizure, exhaust valve seat corrosion or blow-past and turbocharger turbine wheel fouling. This is just a shortlist of potential problems (UK Chamber of Shipping 2013; MAN Diesel \& Turbo 2010). Despite the fact that changing to LSMGO can lead to several engine problems this method is technically feasible. However, significant price spread between IFO and LSMGO will lead to price rise of vessels operation.

Over the last 13 years price of crude oil increased 3.35 times: from $158.28 € / \mathrm{t}$ in 2000 to $530.02 € / \mathrm{t}$ in 2013 . During the same period prices of LSMGO increased almost 4 times: from $194.35 € / t$ in 2000 to $754.87 € / t$ in 2013. Today the price difference between IFO and LSMGO is about $50 \%$. However, fuel price differences are expected to increase even further in 2015 when the $0.1 \% \mathrm{SO}_{\mathrm{x}}$ limit comes into force. Increased operational costs will result in the rise of ticket prices to passenger farriers or freight/container customers. At this stage of the investigation the current fuel price is used to calculate the economic impact of switching to LSMGO.

Table 5. Specifications of marine fuels

\begin{tabular}{|c|c|c|c|c|c|}
\hline Industrial name & $\begin{array}{l}\text { Name according } \\
\text { to ISO }\end{array}$ & Composition & $\begin{array}{l}\text { ISO sulphur } \\
\text { weight [\%] }\end{array}$ & $\begin{array}{l}\text { Actual sulphur } \\
\text { weight [\%] }\end{array}$ & $\begin{array}{c}\text { Price }^{*} \\
{[€ / t]}\end{array}$ \\
\hline $\begin{array}{l}\text { Intermediate Fuel Oil } \\
380 \text { (IFO380) }\end{array}$ & $\begin{array}{l}\text { RMG380 } \\
\text { RMH380 }\end{array}$ & $\begin{array}{l}98 \% \text { residual \& } 2 \% \\
\text { distillate oil }\end{array}$ & $\begin{array}{l}\text { Statutory requirements } \\
(3.5 \%)\end{array}$ & $2.67 \%$ world average & 487.45 \\
\hline $\begin{array}{l}\text { Intermediate Fuel Oil } \\
180(\text { IFO180) }\end{array}$ & $\begin{array}{l}\text { RME180 } \\
\text { RMF180 }\end{array}$ & $\begin{array}{l}88 \% \text { residual \& } 12 \% \\
\text { distillate oil }\end{array}$ & $\begin{array}{l}\text { Statutory requirements } \\
(3.5 \%)\end{array}$ & $2.67 \%$ world average & 517.74 \\
\hline $\begin{array}{l}\text { Low Sulphured } \\
\text { Intermediate Fuel Oil } \\
380 \text { (LSIFO380) }\end{array}$ & - & - & Not given & $\begin{array}{l}\text { On market meeting } \\
1 \% \text { specification }\end{array}$ & 539.68 \\
\hline $\begin{array}{l}\text { Low Sulphured } \\
\text { Intermediate Fuel Oil } \\
180 \text { (LSIFO180) }\end{array}$ & - & - & Not given & $\begin{array}{l}\text { On market meeting } \\
1 \% \text { specification }\end{array}$ & 557.97 \\
\hline $\begin{array}{l}\text { Marine Diesel Oil } \\
(\mathrm{MDO})\end{array}$ & DMB & $\begin{array}{l}\text { Distillate with trace } \\
\text { of residual oil }\end{array}$ & $2 \%$ & $0.65 \%$ world average & 732.81 \\
\hline Marine Gas Oil (MGO) & DMA & $100 \%$ distillate oil & $1.5 \%$ & $\begin{array}{l}0.38 \% \text { world average. } \\
\text { On market meeting } \\
0.1 \% \text { specification }\end{array}$ & 754.87 \\
\hline Marine Gas Oil (MGO) & DMX & $100 \%$ distillate oil & $1 \%$ & $\begin{array}{l}\text { On market meeting } \\
0.1 \% \text { specification }\end{array}$ & 754.87 \\
\hline $\begin{array}{l}\text { Low Sulphur Marine } \\
\text { Gas Oil (LSMGO) }\end{array}$ & - & $100 \%$ distillate oil & Not given & $\begin{array}{l}\text { On market meeting } \\
0.1 \% \text { specification }\end{array}$ & 754.87 \\
\hline
\end{tabular}

^Prices from http://www.bunkerworld.com for 20 May 2013 at Rotterdam. 
The propulsion system of a vessel works on different load in accordance with the terms of operating (ISO 8178-1:2006). The terms of operating (E2, E3 and D1) depend on the engines type (main and auxiliary) and the type of propeller (with fixed or controllable pitch) (Woodyard 2009; Mollenhauer, Tschöke 2010). Respectively, specific fuel consumption varies depending on the load of engine and propeller characteristics. At the initial stage of the investigation, the assumption of a constant value of fuel consumption on different modes of operation has been made. The assumed value of consumption is constant and equal to specific fuel consumption. This assumption is close to the real dependence of specific fuel consumption of the main engine. By making the following assumption we get the simplified equations of fuel consumption on operating mode:

$$
G_{f c y c l e}=P_{e n} \cdot b_{e n} \cdot \sum_{i=1}^{n} \bar{P}_{e} \cdot w_{i}[\mathrm{t} / \mathrm{h}],
$$

where: $P_{e n}-$ the nominal power $[\mathrm{kW}] ; b_{e n}-$ specific fuel consumption $[\mathrm{g} / \mathrm{kW} \cdot \mathrm{h}] ; \bar{P}_{e n}$ - the relative power of ship propulsion on operating mode $[\mathrm{kW}] ; w_{i}$ - weighting factors of particular engine modes.

The weighting factors $w_{i}$ of particular engine modes $(100 \%, 75 \%, 50 \%$ and $25 \%$ of load) were taken into account to calculate the difference between using IFO and LSMGO. Weighting factors for E2 and E3 are the same and equal: to 0.2 with $100 \%$ load; 0.5 with $75 \%$; 0.15 with $50 \%$ and $25 \%$ (ISO $8178-1: 2006$ ). As a result $G_{\text {fycle }}$ can be written:

$G_{\text {fycle }}=P_{\text {en }} \cdot b_{\text {en }} \cdot(1 \cdot 0.2+0.75 \cdot 0.5+0.15 \cdot 0.5+0.15 \cdot 0.25)=$

$P_{\text {en }} \cdot b_{\text {en }} \cdot 0.6875 \cdot 10^{-6}[\mathrm{t} / \mathrm{h}]$.

Specific fuel consumption and transit time are the main parameters when calculating the potential effect of increased operational cost of the analysed vessels (Table 6).

Consequently, the operational cost with LSMGO will increase to $150 €$ for a containership ant to $1150 €$ for a passenger ferry per one motor hour in comparison with IFO. Obviously, the rise of operational costs depends on the time in ECA: the longer the vessel is in the ECA the more LSMGO it used (Fig. 2). The transit time in ECA for selected group of vessels is: $100 \%$ for passenger ferry and from $0 \%$ to $75 \%$ for reefers and containerships.

The degree of relative influence on \% increase of fuel costs is the same for examined main engines. However, there are different values of conditionality: for Ferry 25.2 MW increase of fuel costs in 100\% ECA is almost $800 € / \mathrm{h}$; for Reefer $5.3 \mathrm{MW}$ increase of fuel costs in $100 \%$ ECA does not reach $200 € / \mathrm{h}$.

Scrubber's manufacturers consider $25 \%$ time in ECA as a starting point for exhaust cleaning system installation. However, this fact should be checked considering the engine type and specific fuel consumption of the particular vessel.

Scrubbers. The alternative to low sulphur fuel is the after-treatment of exhausts. A scrubber operating at $67 \%$ efficiency could enable a ship to burn $4.5 \%$ sulphur fuel and still meet $1.5 \% \mathrm{SO}_{\mathrm{x}}$ requirements. Scrubber tests and

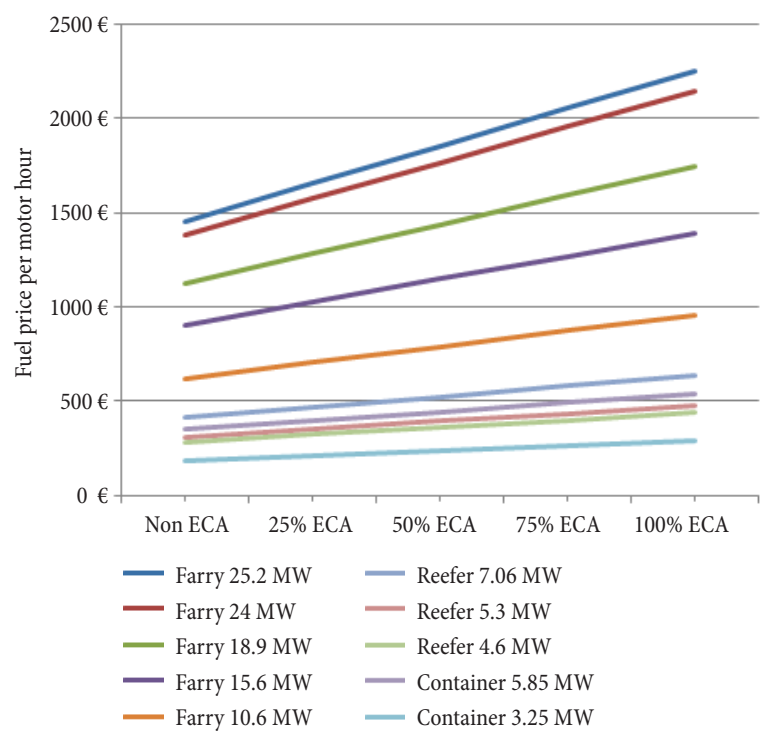

Fig. 2. Operational cost of each vessel depending on time in ECA

Table 6. Price spread between IFO, MDO and LSMGO per motor hour

\begin{tabular}{|c|c|c|c|c|c|c|c|}
\hline $\begin{array}{l}\text { Ship type and } \\
\text { engines power }\end{array}$ & $\begin{array}{c}b_{e n} \\
{[\mathrm{~g} / \mathrm{kWh}]}\end{array}$ & $\begin{array}{c}G_{f \text { cycle }} \\
{[\mathrm{t} / \mathrm{h}]}\end{array}$ & $\begin{array}{c}\text { IFO price } \\
{[€ / \mathrm{h}]} \\
(487.45 € / \mathrm{t})\end{array}$ & $\begin{array}{c}\text { MDO price } \\
{[€ / \mathrm{h}]} \\
(732.81 € / \mathrm{t})\end{array}$ & $\begin{array}{c}\text { LSMGO price } \\
{[€ / \mathrm{h}]} \\
(754.87 € / \mathrm{t})\end{array}$ & $\begin{array}{c}\text { Price spread } \\
\text { IFO\&MDO } \\
{[€ / h]}\end{array}$ & $\begin{array}{c}\text { Price spread } \\
\text { IFO\&LSMGO } \\
{[€ / \mathrm{h}]}\end{array}$ \\
\hline Ferry $25.2 \mathrm{MW}$ & 172 & 2.98 & 1453 & 2184 & 2249 & 731 & 797 \\
\hline Ferry $24 \mathrm{MW}$ & 172 & 2.84 & 1383 & 2080 & 2142 & 696 & 759 \\
\hline Ferry $18.9 \mathrm{MW}$ & 178 & 2.31 & 1127 & 1695 & 1746 & 567 & 619 \\
\hline Ferry $15.6 \mathrm{MW}$ & 172 & 1.84 & 899 & 1352 & 1393 & 453 & 493 \\
\hline Ferry $10.6 \mathrm{MW}$ & 174 & 1.27 & 618 & 929 & 957 & 311 & 339 \\
\hline Reefer 7.06 MW & 174 & 0.84 & 412 & 619 & 638 & 207 & 226 \\
\hline Reefer 5.3 MW & 174 & 0.63 & 309 & 464 & 478 & 155 & 169 \\
\hline Reefer 4.6 MW & 184 & 0.58 & 283 & 426 & 439 & 143 & 156 \\
\hline Container $5.85 \mathrm{MW}$ & 178 & 0.72 & 349 & 525 & 540 & 176 & 191 \\
\hline Container $3.25 \mathrm{MW}$ & 172 & 0.38 & 187 & 281 & 290 & 94 & 103 \\
\hline
\end{tabular}


trials show $90 \div 99 \%$ efficiency of $\mathrm{SO}_{\mathrm{x}}$ reduction, which allows complying with $0.1 \% \mathrm{SO}_{\mathrm{x}}$ emission requirements. Shipboard scrubbing also helps reduce emissions of particulates but has limited impact on $\mathrm{NO}_{\mathrm{x}}$ (EPA 2008).

The benefits of this method will express themselves when sulphur limits become so low, that they cannot be practically or cost-effectively achieved by removing sulphur from residual fuel. Due to the price rise of low sulphur fuel, scrubbers are becoming one of the most realistic alternatives to comply with the IMO requirement and that may have significant operational cost saving benefits. The price difference between IFO and LSMGO is an important parameter in choosing a particular method of compliance to IMO requirements. The economic efficiency of scrubbers has been assessed by comparing the equipment price with the cost of using LSMGO. The systems are capable of removing $90 \%$ to $99 \%$ of $\mathrm{SO}_{\mathrm{X}}$, depending upon water temperature and salinity.

There are two types of scrubbers: wet ones and dry ones. Dry scrubber use dry chemical and wet scrubber use water as a scrubbing medium. Fitting dry scrubbers in ships requires placing extra dead weights below the water line to compensate for the high location and weight of the scrubber system. This reduces the carrying capacity of the ship and increases fuel consumption even when the ship is in ballast. The dry scrubber is less profitable considering the average age and size of the vessels in the Lithuanian fleet. Therefore, only the wet type scrubbers are analysed in this paper. There are two main types of wet scrubber: one type uses fresh water (close loop) mixed with caustic soda; the other type uses only sea water (open loop). The close loop system use water and caustic soda on a regular basis. The handling of caustic soda on board requires special safety equipment and training. Open loop scrubbers use salt' water and then discharge it back into the sea (Glosten 2011).

If a particular vessel has a short transit time in $\mathrm{ECA}$, or the regulations do not restrict water discharge in the operational region, an open loop scrubber may be appropriate (Lack et al. 2012). Otherwise shipowners have to choose the close loop scrubber.

The mentioned type scrubbers were selected in order to analyse the payback period for every vessel in the selected group. The price of scrubbers ranges from 1 to 3 million $€$ for a new build and from 2 to 4 million $€$ for retrofit. Installation is assumed to be formed by: $50 \%$ - the unit cost, $7 \%$ engineering/design, $2 \%$ training and documentation cost and 250,000 €/year for operating (Wärtsilä 2012; Glosten 2011). The scrubber is installed during planned maintenance. Therefore, losses from shutdowns taken into account in the calculation are zero.

The scrubber type depends on the air flow rate. Accordingly, this characteristic of the engine will influence the process of determining the scrubber type suitable for a particular application. There are 2- and 4-stroke engines in the selected group of vessels. Depending on their characteristics the air consumption should be calculated in order to choose a suitable type of scrubbers:

$$
G_{\text {air }}=G_{f n} \cdot L_{0} \cdot \alpha \cdot \varphi[\mathrm{kg} / \mathrm{h}],
$$

where: $G_{a i r}$ - air consumption $[\mathrm{kg} / \mathrm{h}] ; G_{f n}$ - nominal fuel consumption $[\mathrm{kg} / \mathrm{h}] ; L_{0}-$ stoichiometric air-fuel constant, accepted $14.5 \mathrm{~kg}$ air $/ \mathrm{kg}$ fuel; $\alpha$ - real coeffi-

Table 7. Scrubbers price for different vessels

\begin{tabular}{|c|c|c|c|c|c|c|c|c|c|}
\hline \multirow{2}{*}{ Ship type } & \multirow{2}{*}{ Main engines } & \multirow{2}{*}{ Stroke } & \multirow{2}{*}{$\begin{array}{c}b_{e n} \\
{[\mathrm{~g} / \mathrm{kWh}]}\end{array}$} & \multirow{2}{*}{$\underset{[\mathrm{kg} / \mathrm{kWh}]}{G_{a i r}}$} & \multirow{2}{*}{$\begin{array}{l}\text { Scrubber } \\
\text { type }\end{array}$} & \multicolumn{2}{|c|}{ Scrubber price $[€]$} & \multicolumn{2}{|c|}{ Final price $[€]$} \\
\hline & & & & & & Open loop & Close loop & Open loop & Close loop \\
\hline $\begin{array}{l}\text { Ferry } \\
25.2 \mathrm{MW}\end{array}$ & $\begin{array}{l}2 \times \text { Wärtsilä } \\
12 \mathrm{~V} 46\end{array}$ & 4 & 172 & 5.49 & $25.2 \mathrm{MW}$ & 2380000 & 2990000 & 4034200 & 5004100 \\
\hline $\begin{array}{l}\text { Ferry } \\
24 \mathrm{MW}\end{array}$ & $\begin{array}{l}2 \times \text { Wärtsilä } \\
12 \text { V46 }\end{array}$ & 4 & 172 & 5.49 & $24 \mathrm{MW}$ & 2360000 & 2970000 & 4002400 & 4972300 \\
\hline $\begin{array}{l}\text { Ferry } \\
18.9 \mathrm{MW}\end{array}$ & $\begin{array}{l}\text { MAN B\&W } \\
\text { 9L48/60 }\end{array}$ & 4 & 178 & 5.68 & $18.9 \mathrm{MW}$ & 2260000 & 2860000 & 3843400 & 4797400 \\
\hline $\begin{array}{l}\text { Ferry } \\
15.6 \mathrm{MW}\end{array}$ & $\begin{array}{l}1 \times \text { Wärtsilä } \\
8 \mathrm{R} 46\end{array}$ & 4 & 172 & 5.49 & 15.6 MW & 2200000 & 2800000 & 3748000 & 4702000 \\
\hline $\begin{array}{l}\text { Ferry } \\
10.6 \mathrm{MW}\end{array}$ & $\begin{array}{l}1 \times \text { SKL 6VDS } \\
48 / 42 \text { AL- } 2\end{array}$ & 4 & 174 & 5.55 & $10.6 \mathrm{MW}$ & 1450000 & 1750000 & 2555500 & 3032500 \\
\hline $\begin{array}{l}\text { Reefer } \\
7.06 \mathrm{MW}\end{array}$ & $\begin{array}{l}1 \times \text { Mitsubishi } \\
\text { 8UEC45LA }\end{array}$ & 2 & 174 & 7.32 & 8.9 MW & 1350000 & 1580000 & 2396500 & 2762200 \\
\hline $\begin{array}{l}\text { Reefer } \\
5.3 \mathrm{MW}\end{array}$ & $\begin{array}{l}1 \times \text { Mitsubishi } \\
\text { 6UEC45LA }\end{array}$ & 2 & 174 & 7.32 & $6.5 \mathrm{MW}$ & 1250000 & 1540000 & 2237500 & 2698600 \\
\hline $\begin{array}{l}\text { Reefer } \\
4.6 \mathrm{MW}\end{array}$ & $\begin{array}{l}1 \times \text { MAN B\&W } \\
5 \mathrm{~L} 50 \mathrm{MCE}\end{array}$ & 2 & 184 & 7.74 & $5.8 \mathrm{MW}$ & 1200000 & 1520000 & 2158000 & 2666800 \\
\hline $\begin{array}{l}\text { Container } \\
5.85 \mathrm{MW}\end{array}$ & $\begin{array}{l}1 \times \mathrm{MAN} \\
6 \mathrm{~L} 48 / 60\end{array}$ & 4 & 178 & 5.68 & $5.8 \mathrm{MW}$ & 1200000 & 1520000 & 2158000 & 2666800 \\
\hline $\begin{array}{l}\text { Container } \\
3.25 \mathrm{MW}\end{array}$ & $\begin{array}{l}1 \times \text { Wärtsilä } \\
8 \mathrm{R} 32\end{array}$ & 4 & 172 & 5.49 & $3.2 \mathrm{MW}$ & 1000000 & 1400000 & 1840000 & 2476000 \\
\hline
\end{tabular}


cient of air excess; $\varphi$ - air mass flow ratio, accepted 1.45 for 2-stroke and 1.1 for 4-stroke engine (Mollenhauer, Tschöke 2010).

Because of the higher air consumption in the analysed 2-stroke engines it is required to choose a more powerful scrubber than for a 4-stroke engine. Furthermore, older engines have a higher fuel consumption, which leads to an increase of exhaust gas flow and consequently requires more powerful scrubbers. The determination of scrubber type to selected group of vessels is given in Table 7 (Wärtsilä 2010). The designation of scrubber type was made in accordance with the power of the main engine.

The achieved result shows that the average price (final) of a scrubber, depending on engine power is: for passenger ferries $-270 € / \mathrm{kW}$; for refrigerators $380 € / \mathrm{kW}$; for containerships $-445 € / \mathrm{kW}$.

Furthermore, the scrubber type depends not only on engine power but also on engine type (2- or 4 -stroke). An engine of similar power but with different stroke number requires a more expensive scrubber. For example, analysed refrigerator vessel with $5.3 \mathrm{MW}$ 2-stroke engine requires a 6.5 MW scrubber which cost $2237500 €$ (open loop) or $2698600 €$ (close loop). In turn, a containership with 5.85 MW 4-stroke engine requires a 5.8 MW scrubber that costs $2158000 €$ (open loop) and $2666800 €$ (close loop).

Methodology of the assessment of using scrubbers or LSMGO to comply with MARPOL 73/78 is presented below.

\section{Methodology of the Assessment of Using Scrubbers or LSMGO}

The assessment of feasibility of using scrubbers or LSMGO on board is comprehensive. However, along with the technological aspects the economic aspect is determining for shipowners. In general, the comparison includes an assessment of capital and operating costs associated with the implementation of certain technology (Hulskotte, Denier van der Gon 2010). The ratio of capital and operating costs are different for the mentioned technologies: the capital costs for scrubbers are major; however, the operating costs for LSMGO are dominating due to the higher price of the LSMGO. Therefore, the comparison of economic efficiency of scrubbers and LSMGO should be implemented by taking into account the vessel's operating period $Y$ after the installation of each technology. Obviously, there is a value $Y_{k r}$, in which the costs of using scrubbers and LSMGO are equal:

$$
\left(\Delta C_{f} Y_{k r}-C_{s c r u b} f\left(Y_{k r}\right)\right)=0,
$$

where: $\Delta C_{f}$ - additional annual costs of using LSIFO in comparison with IFO [€/year]; $C_{s c r u b} f\left(Y_{k r}\right)$ - capital (purchase of equipment, installation) and operating costs of scrubbers [€]; $Y_{k r}$ - period of time in which the costs of using scrubbers and LSMGO are equal [year].

Additional annual operating costs of the vessel related with using of replacement of LSMGO determined by the dependence:

$$
\Delta C_{f}=G_{f} \cdot\left(C_{L S I F O}-C_{I F O}\right)[€ / \text { year }],
$$

where: $G_{f}$ - annual fuel consumption [t/year]; $G_{L S I F O}-$ the price of LSIFO $[€ / t] ; G_{I F O}$ - the price of IFO $[€ / t]$.

An additional factor $P \in[0 \ldots 1.0]$ is introduced in Eq. (2) to take into account the operating time in ECA.

As a result $\Delta C_{f}$ can be written:

$$
\Delta C_{f}=G_{f} \cdot\left(C_{L S I F O}-C_{I F O}\right) \cdot P[€ / \text { year }] .
$$

Annual fuel consumption is given by:

$$
G_{f}=\left(\sum_{i=1}^{n} P_{e i} \cdot b_{e i} \cdot w_{i}\right) \cdot k \cdot 10^{-6}[\mathrm{t} / \text { year }],
$$

where: $P_{e n}$ - the effective power on $i$ mode of the operating cycle of ship propulsion, $[\mathrm{kW}] ; b_{e n}$ - the specific fuel consumption on $i$ mode of the operating cycle of ship propulsion $[\mathrm{g} / \mathrm{kW} \cdot \mathrm{h}] ; k$ - annual amount of work of ship propulsion [h/year]; $n-i$ mode operating duty cycle.

It is advisable to use standardized test cycles according to ISO 8178-1:2006 to determine the characteristic operating modes of the ship propulsion. The regulated test cycles for ship propulsion are E2, E3 and D1 (hereinafter operating cycles). By making the assumption of unchanged $b_{e i}=i d e m$ on operating mode (which is confirmed by experimental tests, especially for the main ship propulsion operating on E2) we get:

$$
G_{f}=\left(P_{e n} \cdot b_{e n} \cdot \sum_{i=1}^{n} \overline{P_{e i}} \cdot w_{i}\right) \cdot k \cdot 10^{-6}[\mathrm{t} / \text { year }],
$$

where: $\bar{P}_{e i}-$ the relative power of ship propulsion on operating mode (ISO 8178) $[\mathrm{kW}] ; P_{e n}$ - the nominal power on nominal power mode $[\mathrm{kW}] ; b_{e n}-$ the specific fuel consumption on nominal power mode $[\mathrm{g} / \mathrm{kW} \cdot \mathrm{h}]$.

Substituting Eq. (8) in Eq. (5) we get:

$$
\begin{aligned}
& \Delta C_{f}=\left(P_{e n} \cdot b_{e n} \cdot \sum_{i=1}^{n} \bar{P}_{e i} \cdot w_{i}\right) \cdot k \cdot 10^{-6} \times \\
& \left(C_{L S I F O}-C_{I F O}\right) \cdot P[€ / \text { year }] .
\end{aligned}
$$

The calculations of $\Delta C_{f}$ concerning fuel switching from IFO to LSMGO of Lithuanian fleet are shown in Fig. 3.

Annual costs of scrubber installation and operation are determined:

$$
C_{\text {scrub }} f(Y)=\sum_{j=1}^{m} \frac{C_{s c r u b j}}{Y}+C_{\text {scrubexp }}[€ / \text { year }],
$$

where: $C_{\text {scrub } j}$ - capital (purchase of equipment, installation, training) costs of scrubbers $[€] ; C_{\text {scrubexp }}-$ operating costs [€/year]; $Y$ - operating time of scrubber [year].

Then $\sum_{j=1}^{m} \frac{C_{s c r u b j}}{Y}$, corresponds to an annual amortizable expenses related to capital (purchase of equipment, installation, training) costs of scrubber. 


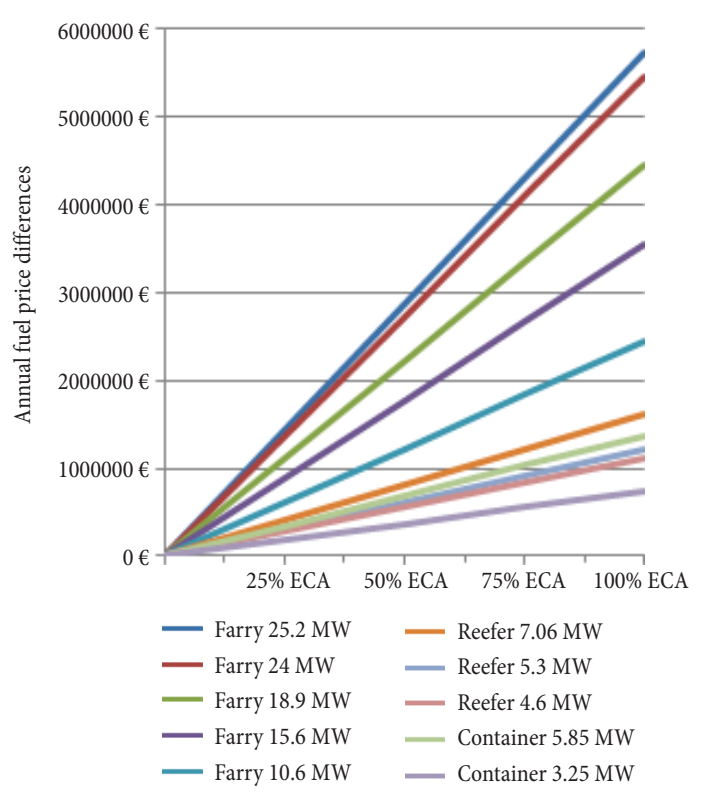

Fig. 3. Annual fuel price differences between using of IFO and LSMGO concerning transit time in ECA

Then, by Eq. (9) and Eq. (10), Eq. (4) becomes (replacing $Y$ with $\left.Y_{k r}\right)$ :

$$
\begin{aligned}
& \left(\left(\left(P_{e n} \cdot b_{e n} \cdot \sum_{i=1}^{n} \bar{P}_{e i} \cdot w_{i}\right) \cdot k \cdot 10^{-6} \times\right.\right. \\
& \left.\left(C_{\text {LSIFO }}-C_{I F O}\right) \cdot P\right) \cdot Y_{k r}- \\
& \left.\left(\sum_{j=1}^{m} \frac{C_{s c r u b j}}{Y_{k r}}+C_{\text {scrubexp }}\right) \cdot Y_{k r}\right)=0 .
\end{aligned}
$$

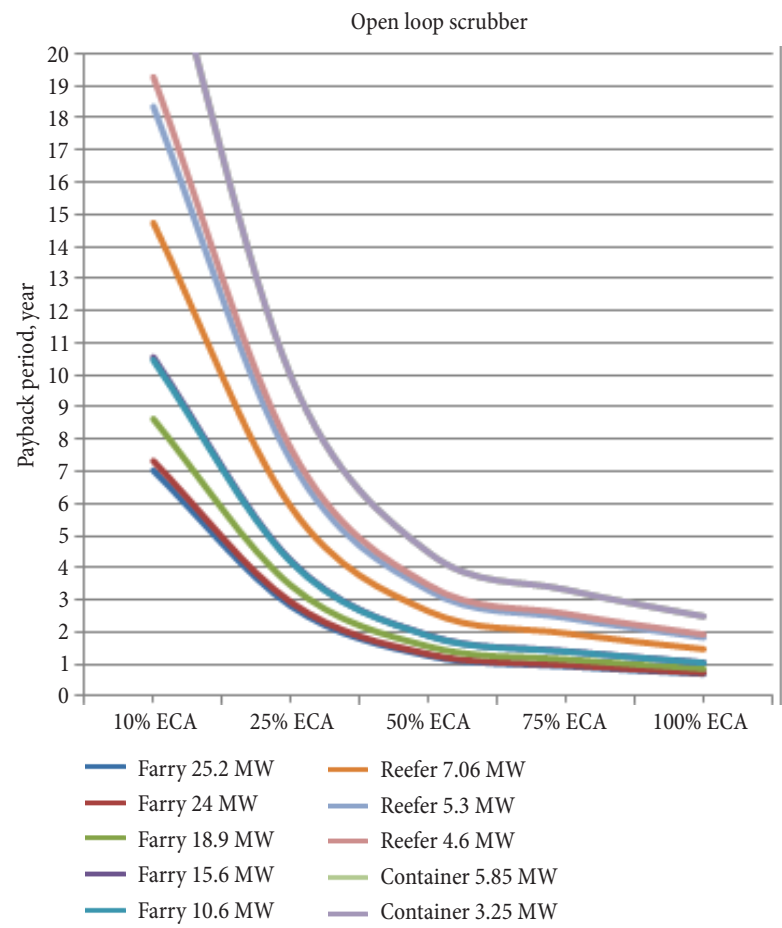

After simplifying the equation, we get:

$$
\begin{aligned}
& \left(\left(\left(P_{e n} \cdot b_{e n} \cdot \sum_{i=1}^{n} \bar{P}_{e i} \cdot w_{i}\right) k \cdot 10^{-6} \times\right.\right. \\
& \left.\left(C_{L S I F O}-C_{I F O}\right) \cdot P\right)- \\
& \left.\left(\sum_{j=1}^{m} \frac{C_{s c r u b j}}{Y_{k r}}+C_{\text {scrubexp }}\right)\right)=0 .
\end{aligned}
$$

The solution of Eq. (12) with set $P$ allows defining operating period of vessel $Y_{k r}$ wherein the costs of using LSMGO and scrubbers become equal.

Obviously, when $Y<Y_{k r}$ it is appropriate to use LSMGO, otherwise, when $Y>Y_{k r}$ the scrubbers will be more profitable.

For practical use the obtained relation (Eq. 12) is non-exhaustive. It is advisable to clarify the structure of operating cycle of ship propulsion: characteristics specific vessels; the dynamics of marine fuel price changing, etc.

As an example, the results of methodology testing on the Lithuanian fleet are shown in Fig. 4.

The deciding factors influencing the investment decision for installation of a scrubber are payback period. The data in Fig. 4 allows determining the payback period of the scrubber in comparison with LSMGO. The analysis of the payback period shows that the return on scrubber investment for some vessels is commercially unprofitable because of their operating area and vessel's characteristics. However, for vessels that have a longer transit time in an ECA scrubbers will have significant

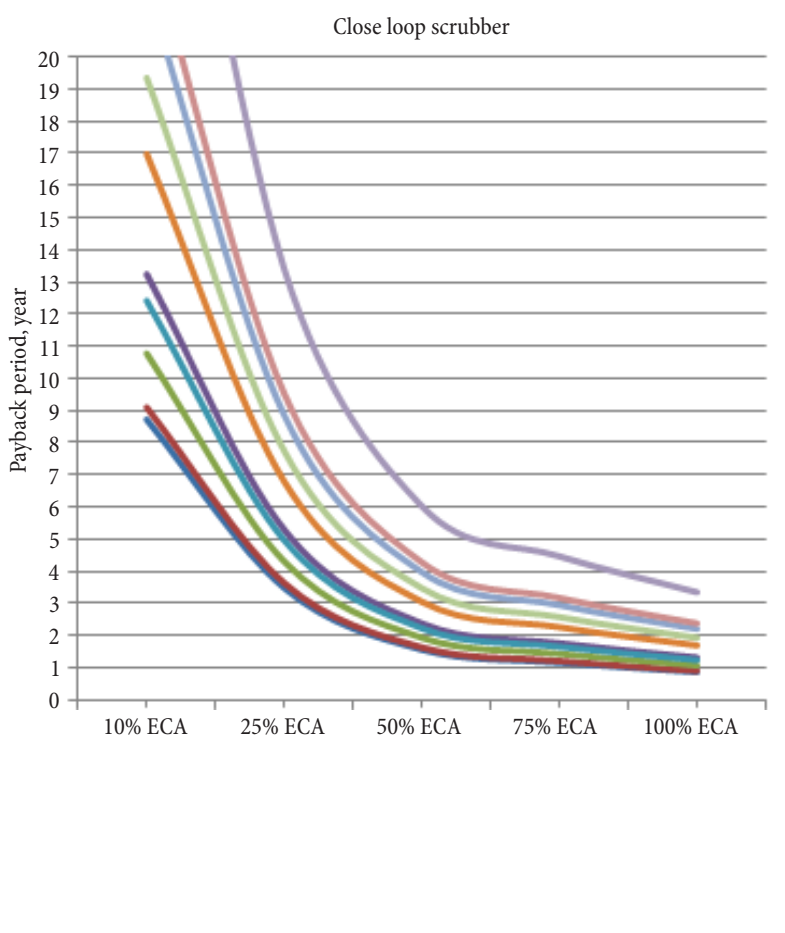

Fig. 4. Advisability of choice between LSMGO and scrubbers for different type of vessel 
operational cost saving benefits and a short payback period:

- for passengers ferries, independently of engine power and scrubber type with $100 \%$ of exploitation in ECA zone, the payback period does not exceed 2 years;

- for refrigerators and containerships, independently of engine power and scrubber type with $100 \%$ of exploitation in ECA zone the payback period does not exceed 3.5 years;

- the payback period for refrigerators and containerships increase to 4 years in 75\% ECA, to 6 years in $50 \% \mathrm{ECA}$ and to 13 years in $25 \% \mathrm{ECA}$;

- there is an insignificant difference between using open and close loop scrubbers. However, the payback period may increase to 13 years for close loop scrubber and 9 years for open loop scrubber in comparison.

\section{Conclusion}

1. The assessment of the structure of the Lithuanian fleet allows to state that most vessels may be retrofitted to use LSMGO or have a scrubber installed, in this way complying with the MARPOL 73/78 Annex VI $\mathrm{SO}_{\mathrm{x}}$ requirements.

2. The priority of selection for practical implementation of the mentioned methods is defended by two factors: engine power and transit time in ECA. Scrubber type dependence on the engine type (2- or 4-stroke) is also presented in this article. A similar power engine with different number of stroke requires a more expensive scrubber.

3. The analysis shows that independently of engine power and scrubber type payback period of passengers ferries with 100\% ECA does not exceed 2 years, whereas for refrigerators and containerships bayback period is up to 3.5 years. With decreasing transit time in ECA to $75 \%$ the payback period for refrigerators and containerships increase to 4 years, with transit time in ECA $50 \%$ the payback period is up to 6 years and with $25 \%$ transit time in ECA it is up to 13 years.

4. The achieved result allows performing a differentiated assessment of the use of ship's toxicity reduction methods by taking into account the main engine type and power, transit time through an ECA, operational load cycle, and dynamics of fuel price changes.

\section{References}

Boardley, T. 2012. The shipping industry innovates with new fuels, new engines, and new designs, gCaptain, 6 March 2012. Available from Internet: http://gcaptain.com/fuelsengines-designs

DFDS Seaways. 2013. The DFDS Fleet. Available from Internet: http://www.dfdsgroup.com/ournetwork/fleet/

DNV. 2012. Shipping 2020. Report. Det Norske Veritas AS. 67 p. Available from Internet: http://www.dnv.nl/binaries/shipping\%202020\%20-\%20final\%20report_tcm141-530559.pdf

EPA. 2008. Global Trade and Fuels Assessment - Future Trends and Effects of Requiring Clean Fuels in the Marine Sector.
US Environmental Protection Agency (EPA). 197 p. Available from Internet: http://www.epa.gov/nonroad/marine/ ci/420r08021.pdf

Fridell, E.; Steen, E.; Peterson, K. 2008. Primary particles in ship emissions, Atmospheric Environment 42(6): 11601168. http://dx.doi.org/10.1016/j.atmosenv.2007.10.042

Glosten. 2011. Exhaust Gas Cleaning Systems Selection Guide. The Glosten Associates, US. 154 p. Available from Internet: http://www.marad.dot.gov/documents/Exhaust_Gas_ Cleaning_Systems_Guide.PDF

Hulskotte, J. H. J.; Denier van der Gon, H. A. C. 2010. Fuel consumption and associated emissions from seagoing ships at berth derived from an on-board survey, Atmospheric Environment 44(9): 1229-1236. http://dx.doi.org/10.1016/j.atmosenv.2009.10.018

ISO 8178-1:2006. Reciprocating Internal Combustion Engines Exhaust Emission Measurement - Part 1: Test-Bed Measurement of Gaseous and Particulate Exhaust Emissions.

Kohl, A. L.; Nielsen, R. 1997. Gas Purification. 5th edition. Gulf Professional Publishing. 900 p.

Kruse, C. 2012. Challenges for Shipping Industry: Could New Fuels and Scrubbers be the Answer? Presentation. StenaLine. 22 p. Available from Internet: http://www.markis.eu/ fileadmin/Arkiv/Dokumenter/MARCOD/CarstenKruseStenaLine.pdf

Lack, A. D.; Thuesen, J.; Elliot, R. 2012. Investigation of Appropriate Control Measures (Abatement Technologies) to Reduce Black Carbon Emissions from International Shipping. Study Report. 118 p. Available from Internet: http://www. imo.org/OurWork/Environment/pollutionprevention/airpollution/documents/air\%20pollution/report\%20imo\%20 black\%20carbon\%20final\%20report\%2020\%20november\%202012.pdf

Lloyd's List. 2010a. Suppliers Take New Sulphur Restrictions in Their Stride. Available from Internet: http://www.lloydslist. com/ll/sector/regulation/article341588.ece

Lloyd's List. 2010b. Use of LNG as a Fuel Set to Rise as ECAs Kick in. Available from Internet: http://www.lloydslist.com/ 11/sector/tankers/article341580.ece

Lonati, G.; Cernuschi, S.; Sidi, S. 2010. Air quality impact assessment of at-berth ship emissions: case-study for the project of a new freight port, Science of the Total Environment 409(1): 192-200.

http://dx.doi.org/10.1016/j.scitotenv.2010.08.029

LSCo. 2013. Company Fleet. Limarko Shipping Company AB (LSCo). Available from Internet: http://www.limarko.lt/ shipping.php?en

LSLA. 2013. Jūrų laivu registre ịregistruoti laivai. Lietuvos saugios laivybos administracija (LSLA). Available from Internet: http://www.msa.lt/lt/papildomas-meniu/statistineinformacija_702/juru-laivu-registre-7f1r.html (in Lithuanian).

MAN Diesel \& Turbo. 2011. Legal Regulation Shipping. Available from internet: http://www.mandieselturbo-greentechnology.com/article_007097.html

MAN Diesel \& Turbo. 2010. Operation on Low-Sulphur Fuels: MAN BeW Two-stroke Engines. Copenhagen, Denmark. 21 p. Available from Internet: http://www.mandieselturbo. com/files/news/filesof15012/5510-0075-00ppr_low.pdf

Marine Traffic. 2013. Ships Currently in Range. Available from Internet: http://www.marinetraffic.com/en/ais/index/ships/ range

MEPC. 2008. Regulations for the Prevention of Air Pollution from Ships were Adopted in the 1997 Protocol to MARPOL 
73/78 and are Included in Annex VI of the Convention. Marine Environment Protection Committee (MEPC), International Maritime Organization (IMO), London, UK.

Mollenhauer, K.; Tschöke, H. 2010. Handbook of Diesel Engines. Springer. $656 \mathrm{p}$. http://dx.doi.org/10.1007/978-3-540-89083-6

Motor Ship. 2005. The Definitive Guide to Marine Engines. 2005 Guide: a Comprehensive A-Z Listing of Marine Diesel Engines in Excess of $300 \mathrm{~kW}$. The Motor Ship, Media House, UK. 39 p.

Poplawski, K.; Setton, E.; McEwen, B.; Hrebenyk, D.; Graham, M.; Keller, P. 2011. Impact of cruise ship emissions in Victoria, BC, Canada, Atmospheric Environment 45(4): 824-833. http://dx.doi.org/10.1016/j.atmosenv.2010.11.029

Schembari, C.; Cavalli, F.; Cuccia, E.; Hjorth, J.; Calzolai, G.; Pérez, N.; Pey, J.; Prati, P.; Raes, F. 2012. Impact of a European directive on ship emissions on air quality in Mediterranean harbours, Atmospheric Environment 61: 661-669. http://dx.doi.org/10.1016/j.atmosenv.2012.06.047

UK Chamber of Shipping. 2013. Impact on Jobs and the Economy of Meeting the Requirements of MARPOL Annex VI. Final Report. 75 p. Available from Internet: http://www. ukchamberofshipping.com/media/filer/2013/03/08/amec_ uk_chamber_of_shipping_report_on_impact_of_2015_ sulphur_targets.pdf

Wang, C.; Corbett, J. J. 2007. The costs and benefits of reducing $\mathrm{SO}_{2}$ emissions from ships in the US West Coastal waters, Transportation Research Part D: Transport and Environment 12(8): 577-588. http://dx.doi.org/10.1016/j.trd.2007.08.003

Wärtsilä. 2012. Wärtsilä Freshwater Scrubber: Leading the Way in $\mathrm{SO}_{X}$ Abatement. Public report. Finland. 46 p. Available from Internet: http://www.wartsila.com/file/Wartsila/1278 525906539a1267106724867-Presentation_W

Wärtsilä. 2010. Exhaust Gas Scrubber Installed Onboard MT "SUULA". Public Test Report. Finland. 30 p. Available from Internet: http://www.wartsila.com/file/Wartsila/ en/1278517851584a1267106724867-Wartsila-ScrubberTest-Report-_final_2.pdf

Wärtsilä. 2007. 46 Project Guide. Finland. 210 p. Available from Internet: http://www.wartsila.com/file/Wartsila/en/1278512662688a1267106724867-Wartsila-O-E-W46-PG-M.pdf

Woodyard, D. 2009. Pounder's Marine Diesel Engines and Gas Turbines. 9th edition. Butterworth-Heinemann. 928 p.

Ytsma, R.; Lukszo, Z.; Maliepaard, R. 2009. Sustainable reduction of dredging fleet emissions, Computer Aided Chemical Engineering 26: 1165-1169.

http://dx.doi.org/10.1016/S1570-7946(09)70194-4 